\title{
An Older Klinefelter's Syndrome Case with Bipolar Mood Disorder Living in Rural Area in Turkey
}

\author{
Türkiye Kırsalında Yaşayan Bipolar Mizaç Bozukluğu Olan Yaşlı Bir \\ Klinefelter's Sendromu Vakas1
}

\author{
Hakan Demirci ${ }^{1}$, Metin Arif ${ }^{1}$, Ali Topak ${ }^{2}$, Çetin Turan ${ }^{3}$, Ali Riza Turkoglu ${ }^{4}$, Koray Ayar $^{5}$, Ibrahim Taymur $^{3}$
}

\begin{abstract}
Aim: The aim, in this case, is to report a patient with Klinefelter's Syndrome, living in a rural area, at an advanced age having bipolar disorder. Both of the diseases are usually supposed to be diagnosed earlier. Methods: The patient was evaluated when he visited the family physician in the rural area for follow-up of diabetes mellitus and psychotic disorder within the scope of mobile family medicine services. During the visit, abnormal body structure of the patient attracted notice and the patient further evaluated. Results: Psychometric tests: Young mania rating scale result was found to be $1 / 60$ and the Hamilton depression rating scale result was found to be 27. Measurements: The body measurements of the patient were found to be as follows: height: $197 \mathrm{~cm}$, weight: $129 \mathrm{~kg}$, Body Mass Index: $33.3 \mathrm{~kg} / \mathrm{m}^{2}$, arm span: $197 \mathrm{~cm}$, pubis-to-floor: $107 \mathrm{~cm}$, head-to-pubis: $90 \mathrm{~cm}$, head circumference: $56.5 \mathrm{~cm}$, waist circumference: $130 \mathrm{~cm}$, hip circumference: $110 \mathrm{~cm}$. Laboratory: The patient was diagnosed with pure $\mathrm{KS}$ by chromosome analysis of the peripheral blood. Ultrasonography: Scrotal doppler ultrasound examination revealed that the size of the right testicle was $20 \times 8.5 \times 12.5 \mathrm{~mm}(1.1 \mathrm{ml})$ and the size of the right testicle was $18 \times 8 \times 11 \mathrm{~mm}(0.8 \mathrm{ml})$ and both testicles were visualized to be hypoplastic. Conclusion: The chromosomal anomaly of the patient was diagnosed by a family doctor, who is also a part-time family medicine residency trainee, when the abnormal body structure, bipolar mood disorder, diabetes mellitus and infertility histories were associated. This case is a good example of the holistic approach. Rural medicine that is carried out in the form of mobile family practice in Turkey provided a significant contribution to the diagnosis of Klinefelter's Syndrome in the patient.
\end{abstract}

Keywords:Klinefelter's syndrome, rural medicine, family medicine, bipolar disorder, holistic approach, mobile services, part-time education

\section{ÖZET}

Amaç: Bu olgu sunumunun amac1, kırsal bölgede yaşayan, ileri yaşta bipolar bozukluğu olan bir Klinefelter's Sendromu olgusunu sunmaktır. Her iki hastalığın da daha erken ortaya çıkması beklenirdi. Yöntem: Hasta, Diabetes Mellitus ve psikiyatrik rahatsızlığı sebebiyle, kırsal bölgede, aile hekimi ziyareti sırasında değerlendirildi. Muayene sırasında, anormal vücut yapısı dikkat çekti ve hasta ileri tetkik edildi. Sonuçlar: Psikometrik testler: Young Mani ölçeği 1/60 ve Hamilton Depresyon skalası sonucu 27 bulundu. Ölçümler: Hastanın vücut ölçüleri şu şekildedir; boy: $197 \mathrm{~cm}$, ağırlık: $129 \mathrm{~kg}$, Vücut Kitle İndeksi: 33,3 kg/m², kulaç uzunluğu: $197 \mathrm{~cm}$, kalça çevresi: $110 \mathrm{~cm}$. Laboratuar: Hastaya periferik kan kromozomal analizinde saf Klinefelter's Sendromu olarak tanı kondu. Ultrason: Skrotal ultrasonda sağ testis büyüklüğü $20 \times 8,5 \times 12,5 \mathrm{~mm}(1,1 \mathrm{ml})$ ve sol testis büyüklüğü $18 \times 8 \times 11 \mathrm{~mm}(0,8 \mathrm{ml})$ olarak ölçüldü ve her iki testis hipoplazik olarak değerlendirildi. Sonuç: Kromozomal anomali, aynı zamanda yarı zamanlı aile hekimliği uzmanlık öğrencisi olan bir aile doktoru tarafindan, anormal vücut görünümü, bipolar mizaç bozukluğu, diabetes mellitus ve infertilite öyküleri birleştirilerek konulmuştur. Bu olgu bütüncül yaklaşım için güzel bir örnektir. Türkiye'de aile hekimleri tarafından yürütülen kırsal hekimlik hizmetinin de bu hastada Klinefelter's sendromu tanısı koymada katkısı vardır.

Anahtar kelimeler: Klinefelter's sendromu, kırsal hekimlik, aile hekimliği, bipolar bozukluk, bütüncül yaklaşım, mobil hizmetler, yarı zamanlı eğitim

Received / Geliş tarihi: 12.02.2018, Accepted / Kabul tarihi: 01.05.2018

${ }^{1}$ Family Medicine, University of Health Sciences Bursa Yuksek Ihtisas Training and Research Hospital

${ }^{2}$ Genetics, University of Health Sciences Bursa Yuksek Ihtisas Training and Research Hospital

${ }^{3}$ Psychiatry, University of Health Sciences Bursa Yuksek Ihtisas Training and Research Hospital

${ }^{4}$ Urology, University of Health Sciences Bursa Yuksek Ihtisas Training and Research Hospital

${ }^{5}$ Rheumatology, University of Health Sciences Bursa Yuksek Ihtisas Training and Research Hospital

*Address for Correspondence / Yazıșma Adresi: Hakan Demirci. Family Medicine, University of Health Sciences Bursa Yuksek Ihtisas Training and

Research Hospital, Bursa-TÜRKIYYE, E-mail:drhakandemirci@hotmail.com

Demirci H, Arif M, Topak A, Turan Ç, Turkoglu AR, Ayar K, Taymur İ.Türkiye Kırsalında Yaşayan Bipolar Mizaç Bozukluğu Olan Yaşlı Bir Klinefelter's Sendromu Vakası. TJFMPC, 2018;12 (3): 226-229 .DOI: 10.21763/tjfmpc.452492 


\section{INTRODUCTION}

Klinefelter Syndrome (KS) was first identified in 1942 as an endocrine disorder characterized by small testes, gynecomastia, hypogonadism, and increased excretion of follicle-stimulating hormone (FSH). The disease is the most common sex chromosome aneuploidy in live male births and estimated prevalence of 1 in 500-1000. ${ }^{1,2}$ It is a genetic condition characterized by an $\mathrm{X}$ supernumerary sex chromosome in males. The extra X chromosome is retained because of a nondisjunction event during paternal or maternal meiosis. ${ }^{1}$ About $80 \%$ of $\mathrm{KS}$ are due to known as classical type the congenital numerical chromosome aberration 47, XXY; the remaining $20 \%$ have higher-grade chromosomal aneuploidy, 46, XY/47, XXY mosaicism, or structurally abnormal $\mathrm{X}$ chromosomes. ${ }^{1-3}$

Patients have a phenotype which is extremely variable such as a small testicular size, gynecomastia, euchanoid body habitus, sparse body hair, long arms and legs, elevated gonadotropins, and infertility. ${ }^{2}$ Many patients with KS remain undiagnosed. When clinically evaluated, the diagnosis rate of Klinefelter syndrome is estimated to be $25 \%$. These patients only a minority are diagnosed before puberty. Patients with KS are often diagnosed usually during the examination for infertility. ${ }^{4,5}$

Previous research suggests that bipolar disorder, schizophrenia, and other psychiatric disorders might be overrepresented in patients with $\mathrm{KS} .{ }^{6}$ Over-dosage of X-linked escapee genes due to an extra $\mathrm{X}$ chromosome was suggested to contribute to the development of psychiatric symptoms in $\mathrm{KS}^{7}$

The aim, in this case, is to report a patient with KS at an advanced age having bipolar disorder. This case raises awareness about the psychiatric diagnoses that can be seen frequently in patients with KS whose diagnosis can be delayed as he lives in the rural part of the city.

\section{CASE}

A 63-year-old man with KS, who lives in a rural area, was diagnosed with bipolar disorder by a parttime family medicine residency trainee. The patient was evaluated when he visited the family physician in the rural area for follow-up of diabetes mellitus and psychotic disorder within the scope of mobile family medicine services.

When the medical history about the psychiatric complaints of the patient was obtained, it was detected that he had complaints of insomnia, nervousness, and hyperactivity 15 years ago and that he was diagnosed with bipolar disorder by a psychiatrist. Until today, he has been hospitalized three times (the first hospitalization was 15 years ago when the first complaints began, the second one was 10 years ago and the third one was three months ago) in Psychiatry Clinic for a manic episode. It was detected that there were also mild depressive episodes among the patient's previous complaints but he did not visit a doctor for the treatment of that. His treatment has still been continued with $1000 \mathrm{mg}$ of valproic acid per day and $20 \mathrm{mg}$ of aripiprazole per day. The drug level of valproic acid was found to be $52 \mathrm{mg} / \mathrm{L}$ (normal range: $50-100)$ in the performed test. Young mania rating scale result was found to be $1 / 60$ and the Hamilton depression rating scale result was found to be 27. The patient was evaluated to be in a depressive episode. Any confusion or delusional history was not identified. His IQ was measured to be 72. It was learned that he had difficulty in learning how to read and write in primary school. Mini-mental test result was found to be normal (test score: 27).

It was learnt from the medical history of the patient that he has been having diabetes mellitus 10 years and used oral antidiabetic drugs (gliclazide

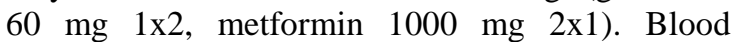
glucose regulation could not be achieved (HbA1c: 9 $\mathrm{mg} / \mathrm{dL}$ ). There was no history of hypertension, blood pressure was measured to be $120 / 80 \mathrm{mmHg}$. The patient has been married for 45 years and has no children. He specified that he has always had a problem with erectile function. He had attempted to have a child, but could not obtain any result. There was no history of chromosomal anomaly during that period. There is no family history of infertility.

\section{CLINICAL AND LABORATORY FINDINGS}

The patient was diagnosed with KS by chromosome analysis of the peripheral blood (Picture1 \& Picture2).

The body measurements of the patient were as follows: height: $197 \mathrm{~cm}$, weight: $129 \mathrm{~kg}$, BMI: 33.3, arm span: $197 \mathrm{~cm}$, pubis-to-floor: $107 \mathrm{~cm}$, head-to-pubis: $90 \mathrm{~cm}$, head circumference: $56.5 \mathrm{~cm}$, waist circumference: $130 \mathrm{~cm}$, hip circumference: $110 \mathrm{~cm}$ (Picture3).

Scrotal doppler ultrasound examination revealed that the size of the right testicle was $20 \times 8.5 \times 12.5 \mathrm{~mm}(1.1 \mathrm{ml})$ and the size of the right testicle was $18 \times 8 \times 11 \mathrm{~mm}(0.8 \mathrm{ml})$ and both testicles were visualized to be hypoplastic.

Hormone levels were detected to be as follows: FSH: $26.54 \mathrm{mIU} / \mathrm{ml}(1.4-18.1)$, $\mathrm{LH}$ : 12.27mIU/ml (1.5-9.3), Estradiol: $14.95 \mathrm{pg} / \mathrm{ml}(0-$ 39.8), Total Testosterone: $69.45 \mathrm{ng} / \mathrm{dl}$ (241-827), TSH: $4.68 \mathrm{uIU} / \mathrm{ml}(0.4-4.5)$, Vit D: $10,4 \mathrm{ng} / \mathrm{ml}(20-$ 65), PTH: 37,5 (18.5-88). 


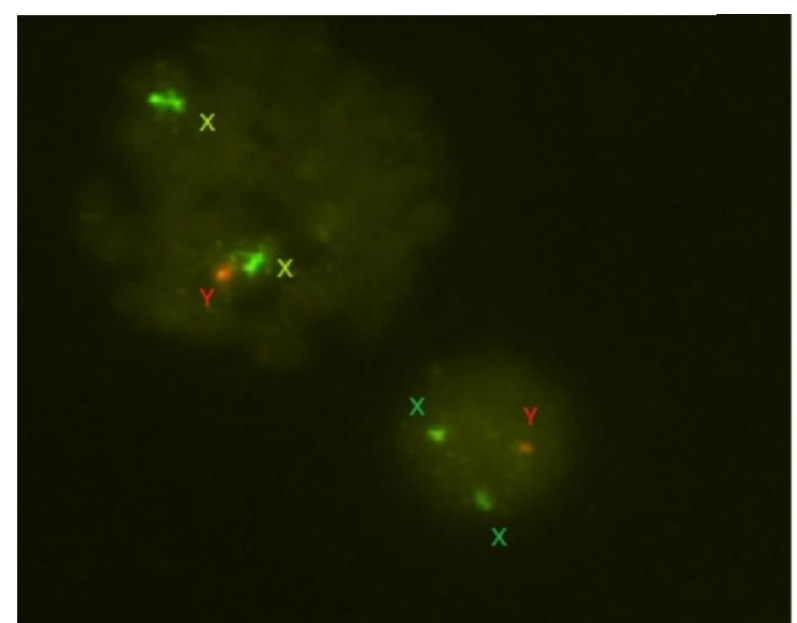

Picture1. $X$ and Y chromosomes (The fish analysis)

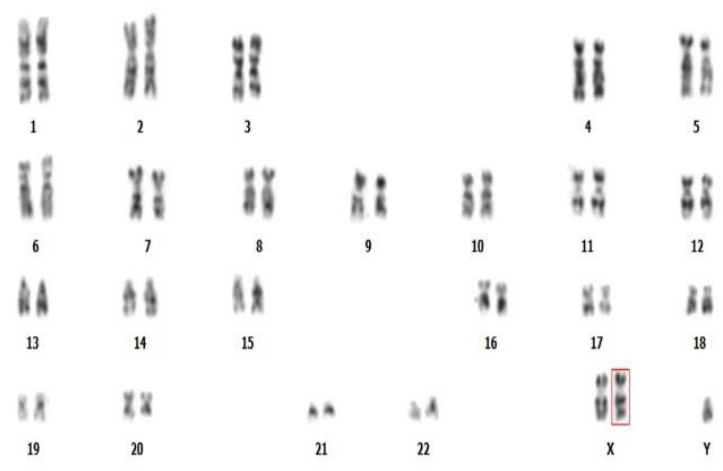

Picture 2. 47XXY (The karyotype analysis)

The autoimmune markers were within normal limits: A-TPO: $51.5 \mathrm{IU} / \mathrm{ml}(0-57)$, Anti TG: $<15 \mathrm{IU} / \mathrm{ml}$ (0-114), RF: $12.7 \mathrm{IU} / \mathrm{ml}$ (0-15), CRP: $3.02 \mathrm{mg} / \mathrm{l}(0-5)$, Sedimentation: $20 \mathrm{~mm} / 60 \mathrm{~min}$ $(<20)$.

When the patient was evaluated in terms of autoimmune disease, initially the patient's systemic questioning was performed and no complaint of Raynaud's phenomenon, photosensitivity, muscle weakness, muscle pain, joint pain, rash was detected, and also complaint of mouth and eye dryness was questioned with sicca symptom questionnaire used for the classification of Sjögren's syndrome within classification criteria proposed by the American-European Consensus Group, and no symptom of sicca was detected (4). Moreover, the questioning of inflammatory lower

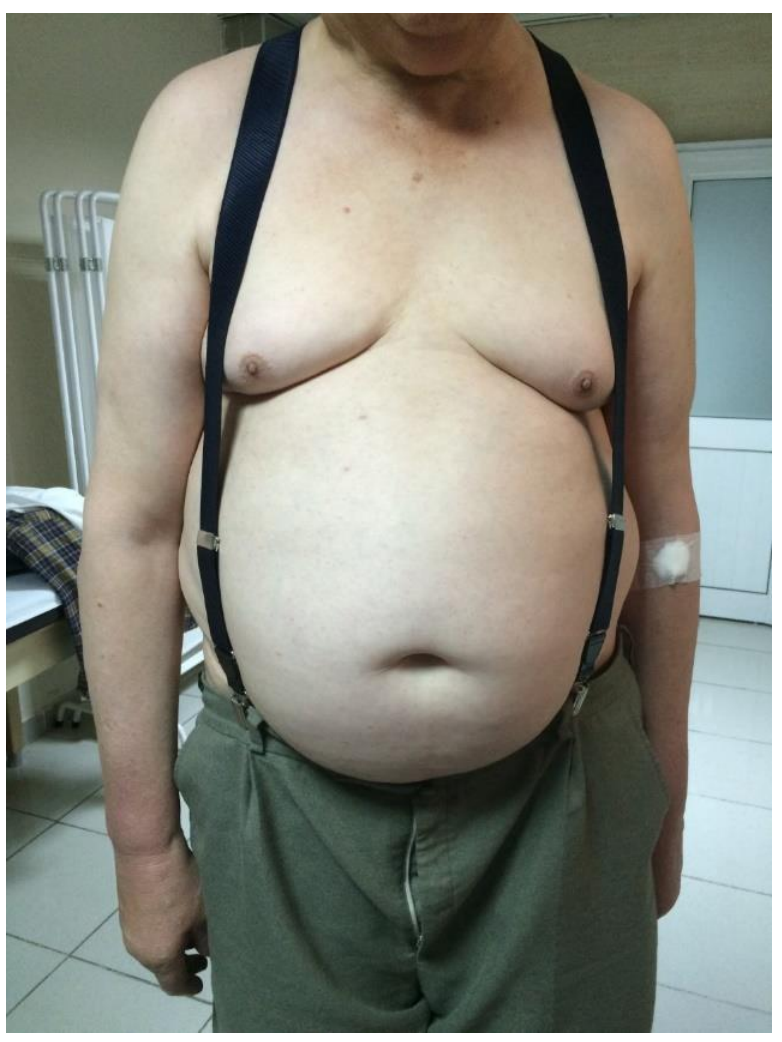

Picture 3. Appearance of the patient with Klinefelter's Syndrome back pain was assessed by the ASAS criteria used for the classification of axial spondyloarthropathy, and no inflammatory lower back pain was detected (5). Physical examination of the musculoskeletal system revealed no swelling, no tenderness or limitation of motion, no muscle weakness, and the Faber test was bilateral negative and no sacroiliac sensitivity was detected. In the autoantibody tests of the patient, the ANA test that was examined with an indirect immunofluorescence technique was negative. RF and anti-CCP tests were found to be negative by nephelometric measurement. Concomitant connective tissue disease or spondyloarthropathy was not detected in the patient based on the present findings.

Plain chest X-ray showed no pathology. 
An anechoic cortical cyst with thin septation, $40 \times 33 \mathrm{~mm}$ in size, was visualized in the middle part of the left kidney as a result of abdominal ultrasonography. The echogenicity of the liver parenchyma has increased, suggesting grade 2 hepatosteatosis. The spleen was normal. There was no mass or lymphadenopathy. There was no free intra-abdominal fluid.

Thyroid and neck ultrasonography revealed that the echogenicity of the thyroid parenchyma was heterogeneous, the contours were partially lobulated (thyroiditis?), and there were linear echogenic bands in the parenchyma. A hypoechoic heterogeneous nodule, $5 \times 2.5 \mathrm{~mm}$ in size, was visualized in the right superior part of the thyroid.

There was no finding suggesting any mass or AV malformation on the cranial computed tomography.

Bone Densitometry revealed a bone mineral density (BMD) value of $0.912 \mathrm{~g} / \mathrm{cm} 2$ with a T-score of $-1.6(82 \%)$ in the L1-L4 region of the spine (osteopenia).

Cardiologic examination revealed no pathological finding and echocardiographic examination was within normal limits.

\section{DISCUSSION}

This patient is a KS patient with bipolar disorder who lives in a rural area. KS patients are usually diagnosed due to reading and writing difficulties or delayed puberty. In cases where delayed puberty was not noticed, infertility is a diagnostic cause. Although the patient had all of these conditions in his history, he has not been diagnosed with KS. Furthermore, the patient had psychiatric problems according to his history; however, he was not diagnosed with this disease until his hospitalization. Although he was diagnosed 15 years ago, he did not have regular follow-up and treatment and was only hospitalized during exacerbations, since he has lived in a rural area. Delayed diagnosis and difficulties in psychiatric follow-up are common in patients living in rural areas.

The cytogenetic analysis of the patient's peripheral blood revealed 47, XXY karyotype. The patient is a pure $\mathrm{KS}$ patient. He has phenotypic characteristics of Klinefelter syndrome. Bilateral testicular aplasia was detected in the performed examination. According to his anamnesis about infertility, he stated that he visited the doctor due to infertility and erectile dysfunction but he did not attend follow-ups visits. If further examination had been performed for infertility, the patient could have been diagnosed with KS earlier.

The chromosomal anomaly of the patient was diagnosed during the mobile family medicine service when the abnormal body structure, bipolar mood disorder, diabetes mellitus and infertility histories were associated. This case is a good example of a holistic approach. Rural medicine that is carried out in the form of mobile family medicine in Turkey provided a significant contribution to the diagnosis of $\mathrm{KS}$ in the patient.

In conclusion, delays in diagnosis of rare diseases are possible in individuals living in rural areas. Early diagnosis is crucial for KS patients, since early diagnosis could provide opportunity for patient's rehabilitation and could even make it possible to have a child. At the same time, the concomitant mood symptoms could be recognized earlier with early diagnosis and the treatment of the patient could be performed in the early period.

\section{REFERENCES}

1. Herlihy AS, Halliday JL, Cock ML, McLachlan RI. The prevalence and diagnosis rates of Klinefelter syndrome: an Australian comparison. Medical Journal of Australia 2011;194(1),24.

2. Bojesen A, Gravholt CH. Klinefelter syndrome in clinical practice. Nat Clin Pract Urol 2007; 4: 192-204.

3. Klein DA, Emerick JE, Sylvester JE, Voght KS. Disorders of Puberty: An Approach to Diagnosis and Management. American Family Physician, 2017;96(9):590-599.

4. Simpson JL, De La Cruz F, Swerdloff RS, et al. Klinefelter syndrome: expanding the phenotype and identifying new research directions. Genet Med 2003; 5: 460-468.

5. Corona G, Pizzocaro A, Lanfranco F, Garolla A, Pelliccione F, Vignozzi L, Ferlin A, Foresta C, Jannini EA, Maggi M, Lenzi A, Pasquali D,Francavilla S, Klinefelter ItaliaN Group (KING). Sperm recovery and ICSI outcomes in Klinefelter syndrome: a systematic review and meta-analysis. Human Reproduction Update, 2017;23(3):265-275.

6. Zhang X, Yang J, Li Y, Ma X, Li R. Sex chromosome abnormalities and psychiatric diseases. Oncotarget, 2017:8(3):3969.

7. Ji B, Higa KK, Kelsoe JR, Zhou X. Overexpression of XIST, the master gene for X chromosome inactivation, in females with major affective disorders. EBioMedicine, 2015;2(8):909-918. 